https://doi.org/10.31108/2.2021.4.24.3

УДК 159.923.2:331

\title{
Tetiana Dziuba
}

\section{TEACHERS' OCCUPATIONAL HEALTH IN THE SPECTRUM OF LEVEL AND CRITERION APPROACHES}

Dziuba Tetiana. Teachers' occupational health in the spectrum of level and criterion approaches.

Introduction. The latest perspective on understanding the nature of teachers' occupational health allows us to consider this phenomenon as a process, in which professional activity becomes consciously built and arbitrarily regulated.

Aim. To clarify the nature of teachers' occupational health by applying level and criteria approaches.

Results. In the level approach, teachers' occupational health is considered as a dynamic construct with a complex multi-level structure. Each level is formed by a number of complementary characteristics and features. Therefore, occupational health can be considered as: a multilevel construct; system property; movement to self-realization; system capable of self-development. The criterion approach structures occupational health in accordance with certain indicators (criteria): the optimal level of professional performance; three-element structure modules; a continuum of criteria; a set of structural and dynamic indicators.

Conclusions. Theoretical and methodological tools of level and criterion approaches open new opportunities for psychological analysis of the nature of teachers' occupational health in educational organizations. Teachers' occupational health can be considered as their ability to make optimal changes, function effectively, as well as develop professionally.

Key words: occupational health, educational organizations, teachers' professional activity, level approach, criterion approach

Дзюба Тетяна. Професійне здоров'я педагога в спектрі рівневого і критеріального підходів.

Вступ. Новітній ракурс осмислення природи професійного здоров'я педагогів дозволяє розглядати ией феномен як процес становлення свідомо вибудуваної й довільно регульованої професійної діяльності.

Метою дослідження є з'ясування природи професійного здоров'я педагогів в спектрі рівневого й критеріального підходів.

Результати. У спектрі рівневого підходу професійне здоров'я педагога розглядається як динамічне утворення, що містить складну структуру рівнів. Кожен рівень утворений низкою взаємодоповнюючих характеристик і ознак. Тому професійне здоров'я можна розглянути як: багаторівневе утворення; системну властивість; рух до самоздійснення; систему здатну до саморозвитку. Критеріальний підхід структуруе професійне здоров'я у відповідності до певних показників (критеріїв): оптимальний рівень професійноі працездатності; трьохелементна структура, що поєднує модулі; континуум критерї̈в; сукупність структурнодинамічних індикаторів.

Висновки. Теоретико-методологічний інструментарій рівневого і критеріального підходів відкриває нові можливості для психологічного аналізу природи професійного здоров'я педагогів в освітніх організаиіях. Розуміння феномену «професійне здоров'я» дозволяє оцінювати його як здатність до оптимальних змін, ефективного функиіонування, професійного розвитку та професійного довголіття праиівника.

Ключові слова: професійне здоров'я, освітні організаиії, професійна діяльність педагогів, рівневий підхід, критеріальний підхід подходов

Дзюба Татьяна. Профессиональное здоровье педагога в спектре уровневого и критериального

Введение. Новый взгляд на природу профессионального здоровья педагогов позволяет рассматривать этот феномен как проиесс становления заведомо выстроенной и произвольно регулируемой профессиональной деятельности.

Целью исследования является установление природы профессионального здоровья педагогов в спектре уровневого и критериального подходов.

Результаты. В спектре уровневого подхода профессиональное здоровье педагога рассматривается как динамическое образование, содержащее сложную структуру уровней. Каждый уровень образован рядом взаимодополняющих характеристик и признаков. Поэтому с точки зрения уровневого подхода профессиональное здоровье можно рассмотреть как: многоуровневое образование; системное свойство; движение $\kappa$ самоосуществлению; систему способную $\kappa$ саморазвитию. Критериальный подход структурирует профессиональное здоровье в соответствии с определенными показателями (критериями): оптимальный уровень профессиональной работоспособности; трехэлементная структура, сочетающая модули; континуум критериев; совокупность структурно-динамических индикаторов.

Выводы. Теоретико-методологический инструментарий уровня и критериального подходов открывает новые возможности для психологического анализа природы профессионального здоровья педагогов 6 образовательных организациях. Понимание феномена «профессиональное здоровье» позволяет оценивать его как 
способность к оптимальным изменениям, эффективному функционированию, профессиональному развитию и профессиональному долголетию работника.

Ключевые слова: профессиональное здоровье, организации образования, профессиональная деятельность педагогов, уровневый подход, критериальный подход

Introduction. Understanding the nature of teachers' occupational health allows us to consider this phenomenon as a process, in which professional activity becomes consciously constructed and arbitrarily regulated. The results of the state-of-the-art research in Ukraine and abroad let us compare the features of the real and the ideal states of teachers' health and choose the most adequate approach in studying this phenomenon.

The analysis of the nature of teachers' occupational health is based on the concepts formulated in the framework of general and organizational psychology research. These are the concepts of organizational development and change management in the organization in conditions of social tension (Karamushka, Kredentser, Tereshchenko, Lagodzinska, Kovalchuk, \& Ivkin, 2020), the concept of «healthy organization» (Karamushka, 2021; Di Fabio, 2017; Lowe, 2020) and the concept of stress (Cooper, Ed. 1998; Peterson, \& Wilson, 2002; Karamushka, 2017).

According to the provisions of these concepts, the essential characteristics of the activities in educational organizations in Ukraine today are as follows:

- educational organizations operate in conditions of prolonged social tension as a mental state of the organization. It is characterized by the exacerbation of internal and external organizational contradictions of objective and subjective nature and is manifested in the individual and group behavior of employees (Karamushka, 2017). From these theoretical positions, the social tension of an educational organization can be a subject of the analysis of potential threats to teachers' occupational health;

- pedagogical activity is characterized as an activity within which the employee is exposed to a number of different and intense stressors. They can provoke and determine the context of groups of threats (risk factors) to the health of all subjects of the educational space. An in-depth study of such threats involves the identification of the prevalence (epidemiology), causality (etiology), phenomenology (symptoms) and their pathogenic impact on teachers' occupational health in educational institutions (Dzuba, 2021).

One of the important aspects of the studied problem is its consideration within the level and criterion approaches.

Aim. To clarify the nature of teachers' occupational health by applying level and criteria approaches as well as to analyze teachers' occupational health in the spectrum of the level approach and to trace the differences of its structural and dynamic characteristics from the standpoint of the criterion approach.

Results. Psychological research traces two approaches to the structure of teachers' occupational health: level and criterion.

Within the level approach, teachers' occupational health can be considered as: multilevel formation; system property; movement to self-realization; a system capable of self-development (Fig. 1).

In the studies of L. M. Mitina, G. V. Mitina, O. A. Asmakovets (2005), teachers' occupational health consists of two levels: the level of self-regulation and the existential level. The level of self-regulation of health ensures the teacher's awareness of the physical level of «I» in the real conditions of the professional environment; forms the ability to vital and professional self-determination; creates a basis for independent design by the teacher of own future, including professional. According to the authors, violations of the mechanisms of self-regulation, deformation of the inner world of the individual become a prolonged cause of a large number of somatic psychological diseases. Confirmation of the connection between self-regulation and occupational health is reflected in the latest foreign studies. B. M. Smit, L. K. Barber (2016) distinguish two factors of attitudes that affect the level of occupational health: dispositional self-control as the ability to regulate thoughts and behavior and daily planning as the ability to self-organize in the space-time continuum. The existential level of health determines the semantic orientations of a teacher and the general meaning of his/her life; forms the teacher's attitude to others and himself/herself; stimulates the development of specific professional abilities (communicative, reflexive, gnostic, creative); provides opportunities for personal choice and autonomous development. This level is an objective condition for the development of the value-semantic attitude of a teacher to own health and the successful implementation of the important prognostic mission of education, which is associated with the creation of a child's spiritual health. Apart from the formation of valuesemantic attitudes to one's own health, «the teacher remains the object of external influences, unable to become the subject of his own life» (Mitina, 2004: 223).

In M. G. Chesnokova's research, the levels of occupational health are structured according to the principle of individualization: the physical level of health is the preservation by an individual of his biological organization and the normal functioning of organs; social level of health - compliance with social norms, compliance with the basic requirements of the individual as a member of society; mental level of health preservation of the function of reflection and regulatory function of the psyche, ensuring the adequacy of the 
subject's behavior to the existing conditions; spiritual level of health - self-realization and self-actualization of the individual, growth of self-awareness, increasing the level of meaningfulness of life (Chesnokova, 2015). According to this principle, a teacher's health is not only a basic condition for effective professional activity (which is more characteristic of the first stages of professionalization) but also as a kind of product of development, as an individual life task of an employee (Chesnokova, 2015:32).

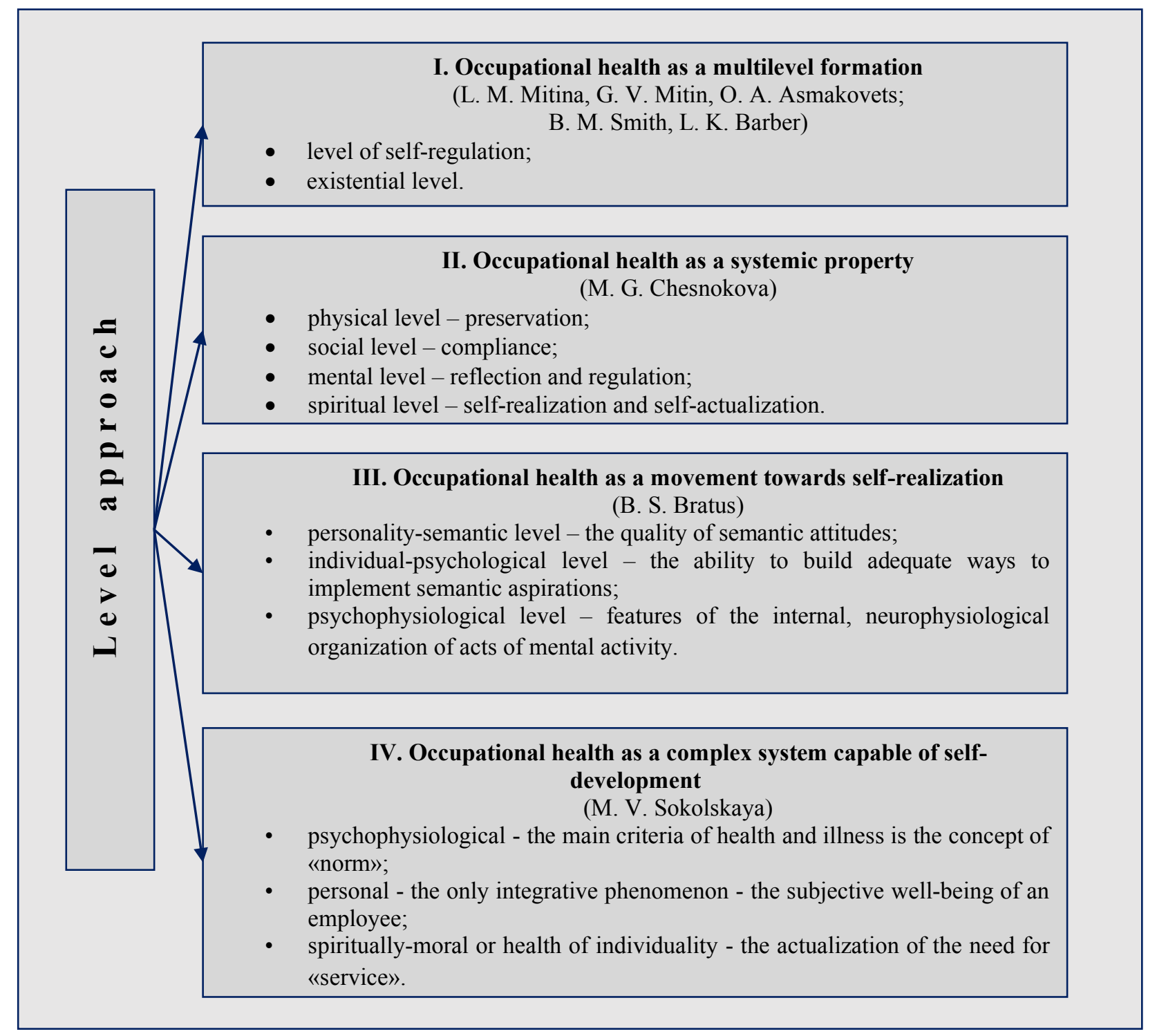

\section{Fig. 1. The levels of teachers' occupational health (level approach)}

B. S. Bratus (2019) builds a hierarchy of levels of health, which shows a movement to self-realization through inclusion in the «ensemble of social relations» through various mechanisms of adaptation and regulation of its relations with the world. The author considers three levels of health: personality-semantic level - is determined by the quality of semantic attitudes of a person; individual-psychological level - fixes a person's ability to build adequate ways to realize semantic aspirations; psychophysiological level - characterizes the features of the internal, neurophysiological organization of acts of mental activity of an individual. Personalitysemantic level as a higher level of health, according to B. S Bratus, relates to the core of personality, given by the system of general semantic formations. «The general semantic formations (in the case of their realization personal values) are the forming units of consciousness of the individual, determine the main and relatively constant attitudes of a person to the main spheres of life» (Bratus, 2019:45). He further notes: «... a person can be completely mentally healthy (remember and think well, set complex goals, find the right ways to them, be active, successful, self-sufficient, etc.) and at the same time personally defective, sick: not coordinate, not direct own life to the achievement of human essence, to be satisfied with surrogate values» (Bratus, 2019:86).

The personal and semantic level of a teacher's health is determined by the quality of his value and semantic attitudes, which mediate the adequacy of perception, the effectiveness of teacher interaction in a 
professional environment, the constructive adaptability to professional activity in a situation of rapid change and educational reconstruction. According to the authors of numerous studies, the value-semantic level is a central component of personal adaptive potential and resources of occupational health (Sinyakova, Pecherkina, \& Churakova, 2021; Karamushka, 2021; Pravdina, Vasilieva, \& Gauss, 2015). For example, in the research of L. M. Karamushka and T. V. Zaichikova (2001) it is shown that pedagogical workers in the conditions of their professional activity gradually form a stage of «resistance» of the general adaptation syndrome, personality is characterized by inadequate selective emotional response, emotional deficit, personal alienation or depersonalization, emotional and moral disorientation, reduction of professional responsibilities. The data obtained in the research of L. A. Martinova, indicate that the greatest degree of expression of mental burnout in the phase of «resistance» is characteristic of teachers aged 28-32 years. Among the teachers of this age group, the symptoms of mental burnout are more regular, protracted and more difficult to correct. This situation, according to the researcher, is explained by the coincidence of two crises: the regulatory crisis of 30 years and the crisis of professional career (according to the periodization of professional development by E. E. Symanyuk) (Martynova, 2015; Symanyuk, 2004). Therefore, the teacher's loss of professional sense of self, the feeling of psychological numbness (personal alienation, depersonalization) and the futility of professional activity become real threats to his/her professional well-being. Depersonalization as a symptom of professional burnout reflects deep deformations of the moral and ethical sphere of the teacher's personality (change of the system of values and meanings, formation of negative professional and life stereotypes and guidelines). This situation is directly related to the deterioration of the subjective neuropsychological status of the teacher, the unresolved problem of effective prevention of professional deformities and professional destruction, crises of professional development and professional growth, shortcomings in the system of prevention of burnout.

M. V. Sokolskaya (2008), based on the understanding of a person as a complex system capable of selfdevelopment, offers a three-tier structure of professional health: the first level - psycho-physiological, i.e., the health of body and individual, where the main criterion of health is the concept of " norm»; the second level personal covers the characteristics of a person as a personality (historical socio-cultural space) and as a subject of activity (professional environment). At this level, occupational health is not a separate element, but as a single integrative phenomenon - the subjective well-being of an employee; the third level - spiritually-moral or health of individuality provides the actualization of the need for «service», which is realized in love for those around, in involvement, interdependence, existential content, which allows an employee to go beyond own actual, available opportunities in the realm of hidden potentials (Sokolskaya, 2008).

Thus, occupational health in the level approach is considered as a formation that contains a complex structure of levels. Each level is formed of complementary characteristics and features. This approach allows us to consider the phenomenon of health as a transition from one level to another, more complex and qualitatively different. Developing the idea of level changes of mental formations, S. L. Rubinstein (2005) remarked: «Each step, being qualitatively different from all others, represents a relative whole, as its psychological characteristic as a certain specific whole is possible. Any previous stage is a preparatory step to the next; within it, those forces and attitudes which, becoming leading, give rise to a new stage of development, grow first as subordinate motives» (Rubinstein, 2005). The level approach makes it possible to clearly distinguish indicators of occupational health development, and the transition from one level to another reflects the dynamics of development of each level in their holistic interaction, becoming a condition or result of the same development. However, we agree with the point of view of M. V. Sokolskaya, who argues that «... achieving a top, higher level of health in the hierarchical development of a person is not sudden - it is a gradual process, which is preceded by a number of stages, levels, in which development is nonlinear and not always consistent: both stops at any stage of development and retrogression are possible, but it is not fatal, because under the active position of personality - its subjectivity further personal development will not only not suffer but also, perhaps, will be more accurate, «purified», conscious, moral» (Sokolskaya, 2008:21). This thesis suggests that such a synergistic phenomenon as «nonlinearity» is an important sign of occupational health. Nonlinearity is the unpredictability of the future state of any system (health as a system, author's note) based on existing ones because any minimal impact (threat) of the environment can cause great consequences («butterfly effect»), and large, on the contrary, may be purely insignificant («a mountain gave birth to a mouse»). The butterfly effect is a term that metaphorically reflects the property of complex interactive nonlinear systems (including those related to the psyche, behavior and social interactions) to change in another dimension and time due to minor and unpredictable events. At the heart of the statement of the American meteorologist Edward Lorenz that the flutter of the butterfly's wings symbolizes small changes in the initial state of the system, which cause a chain of events leading to large-scale changes. Therefore, such systems, on the one hand, are extremely stable in a situation of large-scale adverse effects, and on the other extremely sensitive in the case of minor fluctuations in the environment (Shapoval, \& Turanosova, 2016). In addition, nonlinear systems contain a wide variety of complex feedbacks that determine the possibility of different types of behavior and states and are therefore able to «restructure» from one state to another when the former becomes unfavorable, and therefore nonlinear systems are adaptable.

The criterion approach (Fig. 2) structures occupational health in accordance with certain indicators (criteria). 


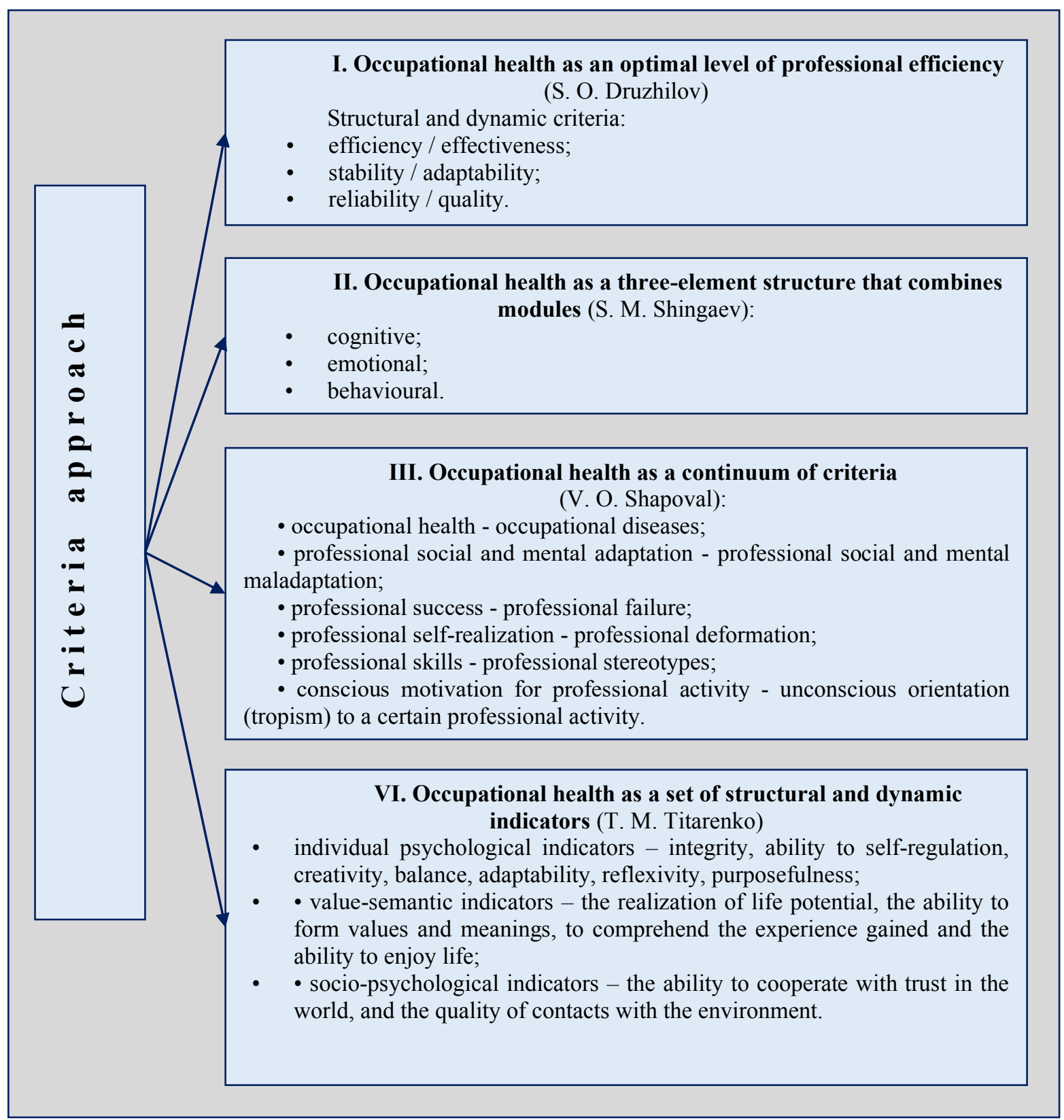

\section{Fig. 2. The levels of indicators of teachers' occupational health (criterion approach)}

It is important to emphasize that, like any system, the «occupational health» system must be characterized by a structure that consists of a system-forming factor (or core) and elements (in our case, criteria). The essence (core) of this system is the optimal level of professional efficiency, and its elements are as follows: efficiency / effectiveness, stability / adaptability, reliability / quality (Druzhilov, 2012). According to S. O. Druzhilov, the effectiveness of professional activity involves comparing the result (effect) with the psychophysiological costs («price of activity»), which are required to obtain this effect (Druzhilov, 2012:17). The effectiveness of professional activity of a teacher is manifested in objective (labour intensity, level of qualification, norms and values of educational organization, formal and informal status of a teacher in the team) and subjective (specific features of professional motivation, level of mental stress, ability to organize their own activities, ease of communication, creativity, the formation of cognitive processes that ensure the successful performance of professional activities, professional self-esteem) indicators (Markova, 1996).

Another pair of criteria - adaptability / stability is determined by the activity of an employee, the ability to adapt own behavior to the changing conditions of the professional environment by modifying motivations, emotions and attitudes. Professional adaptability or the dynamic balance in the system «individual - professional environment», is reflected in the subjective personality traits of an employee, which are dominant in determining the effectiveness of professional activities. However, the dynamic balance of professional and personal development of teachers is quite contradictory and ambiguous. Stressful negative occupational events and prolonged negative occupational influences (such as traumatic occupational experiences and pathogenic 
occupational relationships in a mobbing situation) can both contribute to the development of occupational diseases and mitigate their expression (Popov, Shirenkova, \& Serazetdinov, 2007). If there are stable unfavorable conditions for the professionalization of a teacher, then there is a real threat of maladaptation, or a temporary violation of professional and personal development. For example, excessive unfair and constant criticism, devaluation of a teacher on various vectors of professional interaction can lead to vulnerability; the formation of low self-esteem, which in combination with factors of chronic fatigue, information overload can cause exacerbation of chronic diseases or disease in general. It is also important to consider the fact that each person has a certain barrier to mental adaptation, which seems to absorb all the features of mental composition and the ability to respond. Therefore, as long as a person's behavioral responses are within acceptable limits and do not go beyond the barrier of mental adaptation, the person successfully adapts. However, in the case of its «breakthrough» or «destruction», there is a mental breakdown, which can lead to the development of the disease (Popov, Shirenkova, \& Serazetdinov, 2007).

Thus, adaptability/stability as one of the important indicators of teachers' occupational health is determined by the level of functional strength of the body, resistance to pathological influences (threats) of the professional environment, or how easily and reliably the protective forces compensate for these influences. If a teacher does not have enough internal and external resources to master the tasks of professional and personal development, then for the duration of aggravating processes there is a risk of mental imbalance, which can lead to the development of health disorders in general. Insufficient mastery causes either direct losses in the professional and personal development of a teacher, or increases vulnerability, or possibly increases susceptibility to various pathogenic influences of the organizational educational environment.

The next pair of reliability/quality is determined by the acquisition of professional maturity -individual psychological characteristics of a teacher, which ensures the harmonization of relations in the professional environment, expands and deepens the teacher's ability to correlate their own professional capabilities and needs with professional requirements.

Professional maturity is considered as the highest level of achievements of the subject of activity, as the highest level of manifestation of «high professionalism, qualification and competence» (Chuiko, 2011:187). F. Perls argues that maturity, or mental health, is the ability of an individual to move from reliance on the environment, and from the regulation by the environment to self-reliance and self-regulation. It is about the formation of autonomy as the ability of a mature person not just to rely on oneself, but to trust own inner experience (Perls, 1992). If in the inner experience knowledge and being are completely identical, if for such an experience to be means to know oneself, and to know oneself means to be oneself, then the knowledge that gives the inner experience is knowledge «in essence» (Chuiko, 2011).

Professional maturity as the highest stage of professional development of a teacher involves not only adaptation to rapidly changing conditions of professional activity, but also willingness to realize unique relationships with the world and people through the professional activities. The establishment of professional maturity is associated with the adoption of the mentality of the profession, the emergence of a sense of service to the world through professional activities, when the profession becomes a means of self-realization for a teacher.

On the other hand, the logic of the formation of professional maturity of a teacher creates threats of professional deformities, which are manifested in emotional burnout, alexithymia, excessive deformation of teaching style, daily disorders, personal and professional maladaptation and more. In addition, professional and pedagogical activity is recognized as a profession characterized by a high level of neuroticism - a state of emotional instability, which can lead to neurosis and the manifestation of neurotic tendencies in employee behaviour. The main difference between neurotic disorders is that they affect only certain areas of the mental health of a teacher: they create negative emotional states, limit opportunities for professional realization, significantly impair the quality of professional activities in general.

To reach professional maturity and take responsibility for oneself and one's professional health, a teacher needs to work with the so-called «neurotic levels» in a timely and thorough manner (Perls, 1992). In particular, the level of professional cliché, when a teacher overcomes stereotypes and conformity of behaviour. According to F. Perls, this level determines the playing of non-human roles, as well as controlling games between top-dog and under-dog. The level of professional phobia or artificiality, when professional roles and various professional games dominate, and a teacher seeks support by manipulating others (students, colleagues, parents, supervisor). Awareness of the «falsity» of behaviour and manipulation creates in an employee a sense of fear of being who he/she really is. The level of hopelessness or deadlock is characterized as a situation when the teacher is unable to use the support of the environment and is professionally unprepared to rely on one-self. The level of an internal explosion is when an employee shows the ability to take risks to overcome a level of hopelessness. Willingness not to take on the protective role of the victim (for example in a mobbing situation, etc.). The level of an external explosion or explosion as a deep and intense emotional experience, characterized by the relief and return of emotional balance. This level means the formation of an authentic personality capable of experiencing and expressing their emotions (Perls, 1992). 
Thus, maturity occurs when the teacher mobilizes all resources to overcome the frustration and fear that arise from a lack of support from others.

Within the criteria approach, S. M. Shingayev (2018) defines psychological factors of occupational health as a three-element structure that combines cognitive, emotional, and behavioural modules. The cognitive module of occupational health is manifested in such indicators as an adequate understanding of the level of one's health, awareness of the role of health and its impact on life in general, as well as an understanding of the main risk factors of the profession and ways to maintain and strengthen health. The emotional module covers the whole range of experiences of the state of «health/illness» that arises in an employee in a particular professional situation and is characterized by such a criterion as an adequate emotional response. The criteria of the behavioural module are the characteristics of professional behaviour, which contribute to adaptation to changing conditions of the professional environment, behavioural strategies due to changes in the health of the employee and readiness for a healthy way of organizing professional activities (Shingaev, 2018).

Criteria for occupational psychological health, according to V. O. Shapoval, lie in such continuums as: occupational health - occupational diseases; professional social and mental adaptation - professional social and mental maladaptation; professional success (efficiency, reliability) - professional failure (unreliability, futility); professional self-realization (constructive development, professional transformation) - professional deformation (professional degradation); professional skill (flexibility, creativity, innovation) - professional stereotypes (rigidity, conservatism, dogmatism); conscious motivation for professional activity is an unconscious orientation (tropism) to a certain professional activity (Shapoval, \& Turanosova, 2016).

T. M. Tytarenko analyzes three groups of structural and dynamic characteristics of occupational health: socio-psychological, individual-psychological and value-semantic. The author refers to the individual psychological indicators of teachers' occupational health: integrity, ability to self-regulation, creativity, balance, adaptability, reflexivity, purposefulness. Among the basic value-semantic indicators, which are the second most common, there are four: the realization of life potential, the ability to form values and meanings, to comprehend the experience and the ability to enjoy life. The least common socio-psychological indicators were two integral indicators: the ability to cooperate with trust in the world, and the quality of contacts with the environment, which implies the presence of intimacy, humanity, care (Tytarenko, 2016).

Thus, scientific sources present a wide range of recurring criteria for the occupational health of organizational personnel. Analysis of different points of view on this issue shows that there is no clear, generalized structure, although within the selected criteria there is some semantic identity. Nevertheless, reduction to any one universal criterion is also unproductive.

Conclusions. The analysis of the level and criterion approaches to studying the nature of teachers' occupational health allows us to see the advantages and disadvantages of each approach. The level approach, which is suitable for studying the general health of an individual, somewhat loses its adequacy in the transition to a much more complex phenomenon of occupational health. The criterion approach represents a wide list of repetitive criteria without any classification of features. Therefore, it is appropriate, in our opinion, to apply an integrative approach to the problem. An integrative approach in the study of the phenomenon of teachers' occupational health contains more advantages in the analysis of its structural and dynamic characteristics. This is a promising area for further scientific research and publications.

\section{References}

1. Bratus, B. S. (2019). Anomalii lichnosti. Psihologicheskij podhod. [Personality anomalies. Psychological approach]. OOO TD «Nikeya».[In Russian]

2. Dzuba, T. M. (2021). Vnutrishnij zmist i strukturno-dynamichni xarakterystyky profesijnogo zdorovya pedagogiv: integratyvnyj pidxid. [Internal content and structural-dynamic characteristics of occupational health of teachers: integrative approach]. Zbirnyk naukovykh prats «Visnyk pislyadyplomnoi osvity». Seriya «Socialni ta povedinkovi nauky», 17(46), 4056. https://doi.org/10.32405/2522-9931-2021-17(46)-40-56. [In Ukrainian]

3. Druzhilov, S. A. (2012). Ekologiya cheloveka i professional'noe zdorov'e trudyashchihsya: psihologicheskij podhod. [Human ecology and occupational health of workers: a psychological approach]. Mezhdunarodnyj zhurnal eksperimentalnogo obrazovaniya, 12(2), 15-18. [In Russian]

4. Karamushka, L. M. (2017). Socialna napruzhenist v organizaciyi: sutnist, pidxody do vyvchennya, metodyky doslidzhennya. [Social tension in the organization: essence, approaches to studying, research methods]. Naukove zabezpechennya rozvytku osvity v Ukrayini: aktualni problemy teoriyi i praktyky, VD «Sam», 119-126. [In Ukrainian]

5. Karamushka, L. M. (2021). Psykholohichne zdorov»ya personalu orhanizatsiy v umovakh pandemiyi COVID-19: ohlyad zarubizhnykh doslidzhen'. [Staff's psychological health in the context of the COVID-19 pandemic: a review of foreign studies]. Orhanizatsiyna psykholohiya. Ekonomichna psykholohia, 1(22), 69-78. [In Ukrainian]

6. Karamushka, L. M., \& Zaychykova, T. V. (2001). Problema syndromu «profesiynoho vyhorannya» v pedahohichniy diyal'nosti $\vee$ zarubizhniy ta vitchyznyaniy psykholohiyi. [The problem of the syndrome of «professional burnout» in teaching in foreign and domestic psychology]. Aktualni problemy psykholohii: Naukovi zapysky Instytutu psykholohii im. H.S. Kostuka APN Ukrainy. Nora Druk, 210-217. [In Ukrainian]

7. Karamushka, L. M., Kredentser, O. V., Tereshchenko, K. V., Lahodzinska, V. I., Kovalchuk, O. S., \& Ivkin, V. M. 
(2020). Empirychne doslidzhennya strukturnykh komponentiv psykholohichnoho zdorov»ya personalu osvitnikh orhanizatsiy. [An empirical study on the structural components of the psychological health of the staff of educational organizations]. Aktualni problemy psykholohiyi. Orhanizatsiyna psykholohiya. Ekonomichna psykholohiya. Sotsialna psykholohiya, 57(1), 22-31. [In Ukrainian]

8. Markova, A. K. (1996). Psihologiya professionalizma. [Psychology of professionalism]. [In Russian]

9. Martynova, L. A. (2015). Sindrom emocionalnogo vygoraniya kak faktor, iniciiruyushchij professionalnye krizisy pedagoga. [Burnout syndrome as a factor initiating professional crises of a teacher]. In Gorizonty zrelosti. Sbornik tezisov uchastnikov Pyatoj vserossijskoj na-uchno-prakticheskoj konferencii po psihologii razvitiya, (pp. 433-445) GBOU VPO. [In Russian]

10. Mitina, L. M. (2004). Psihologiya truda i professionalnogo razvitiya uchitelya. [Psychology of work and professional development of the teacher]. Akademiya. [In Russian]

11. Mitina, L. M., Mitin, G. V., \& Anisimova, O. A. (2005). Professionalnaya deyatelnost i zdorove pedagoga. [Professional activity and health of the teacher]. [In Russian]

12. Popov, G. N., Shirenkova, E. V., \& Serazetdinov, O. Z. (2007). Kriterii zdorovya: adaptaciya, socializaciya, individualizaciya. [Health criteria: adaptation, socialization, individualization]. Vestnik Tomskogo gosudarstvennogo pedagogicheskogo universiteta, 5. [In Russian]

13. Pravdina, L. R., Vasileva, O. S., \& Gaus, E. V. (2015). Ekzistencialnaya ispolnennost kak faktor professionalnogo zdorovya. [Existential performance as a factor in occupational health]. Inzhenernyj vestnik Dona, 37(3). [In Russian]

14. Rubinshtejn, S. L. (2005). Osnovy obshchej psihologii. [Fundamentals of General Psychology]. [In Russian]

15. Sinyakova, M., Pecherkina, A., \& Churakova, N. (2021). Professionalnoe zdorove pedagoga. [Occupational health of the teacher]. Litres. [In Russian]

16. Sokolskaya, M. V. (2008). Lichnostnoe zdorove professionala. [Personal health professional]. Izd-vo DVGUPS. [In Russian]

17. Symanyuk, E. E. (2004). Psihologiya professionalno obuslovlennyh krizisov. [Psychology of professionally conditioned crises]. Izd-vo Mosk. psihologo-soc. in-ta. [In Russian]

18. Tytarenko, T. M. (2016). Indykatory psykholohichnoho zdorovya osobystosti. [Individual psychological health indicators]. Psykholohichni nauky: problemy i zdobutky, 9, 196-215. [In Ukrainian]

19. Chesnokova, M. G. (2015). Ponyatie zdorovya v kontekste klyuchevyh kategorij kulturno-deyatelnostnogo podhoda. [The concept of health in the context of key categories of the cultural activity approach]. Vestnik Moskovskogo universiteta. Seriya 14. Psihologiya, 2. [In Russian]

20. Chuyko, O. V. (2011). Osobystisna i profesiyna zrilist: spivvidnoshennya ponyat. [Personal and professional maturity: the relationship of concepts]. Aktualni problemy sotsiolohiyi, psykholohiyi, pedahohiky, 13, 184-190. [In Ukrainian]

21. Shapoval, V. A., \& Turanosova, V. V. (2016). Professionalno-psihologicheskoe zdorove sotrudnikov policii, perezhivshih psihicheskuyu travmu. [Professional and psychological health of police officers who survived mental trauma]. Zdorovye - osnova chelovecheskogo potenciala: problemy i puti ih resheniya, 11(2). [In Russian]

22. Shingaev, S. M. (2018). Psihologicheskoe obespechenie professionalnogo zdorovya vypusknikov vuzov pri adaptacii k professionalnoj deyatelnosti. [Psychological support of occupational health of university graduates in adaptation to professional activity]. Vestnik Omskogo universiteta. Seriya «Psihologiya», 3. [In Russian]

23. Cooper, C. L. (Ed.). (1998). Theories of organizational stress. Oup oxford.

24. Di Fabio, A. (2017). Positive Healthy Organizations: Promoting well-being, meaningfulness, and sustainability in organizations. Frontiers in psychology, 8, 1938.

25. Di Fabio, A., Cheung, F. M., \& Peiró, J. M. (2020). Editorial to special issue «Personality and individual differences and healthy organizations». Personality and Individual Differences, 166, 110-196.

26. Lowe, G. (2020). Creating healthy organizations. University of Toronto Press.

27. Perls, L. (1992). Concepts and misconceptions of Gestalt therapy. Journal of Humanistic Psychology, 32(3), 50-56.

28. Peterson, M., \& Wilson, J. F. (2002). The culture-work-health model and work stress. American Journal of Health Behavior, 26(1), 16-24.

29. Smit, B. W., \& Barber, L. K. (2016). Psychologically detaching despite high workloads: the role of attentional processes. Journal of Occupational Health Psychology, 21(4), 432.

\section{Information about the author}

Дзюба Тетяна Михайлівна, кандидат психологічних наук, доцент, доцент кафедри психології Полтавського національного педагогічного університету імені В. Г. Короленка, Полтава, Україна

Dziuba, Tetiana M., PhD, Associate Professor, V. G. Korolenko Poltava National Pedagogical University, Poltava, Ukraine

E-mail: tatjanadzuba@gmail.com

ORCID ID: https://orcid.org/0000-0002-5950-7741

Отримано 11 жовтня 2021 p.

Рецензовано 22 жовтня $2021 \mathrm{p}$.

Прийнято 25 жовтня 2021 р. 